\title{
RARA Gene Product
}

National Cancer Institute

\section{Source}

National Cancer Institute. RARA Gene Product. NCI Thesaurus. Code C122775.

A protein encoded by the RARA gene. 